\title{
Study the Role of Human Papilloma Virus and Laryngopharyngeal Reflux in Adult Vocal Fold Polyps
}

\author{
A.F.Ghallab ${ }^{1}$, A.F.Allam ${ }^{1}$, S.A.Abdelhay ${ }^{1}$, M.G.Abdelwahab ${ }^{1}$, R.A.Elsayed ${ }^{2}$ and A.A.Abdelalim ${ }^{1}$ \\ ${ }^{1}$ Otorhinolaryngology Dept., Faculty of Medicine, Benha Univ., Benha, Egypt \\ ${ }^{2}$ Medical Microbiology and Immunology Dept., Faculty of Medicine, Benha Univ., Benha, Egypt \\ E-Mail: A.A.Abdelalim@gmail.com
}

\begin{abstract}
There are a few potential reasons for vocal overlap polyps in grown-ups. The mechanical harm is the fundamental driver for polyp arrangement. Laryngopharyngeal reflux and human papilloma infection are conceivable co-factors. The point of this examination was to discover the related parts of laryngopharyngeal reflux and human papilloma infection in the advancement of grown-up vocal crease polyps. This cross-sectional observational investigation included 50 grown-up patients gave vocal crease polyps. Patients were preoperatively evaluated for the presence of laryngopharyngeal reflux utilizing the approved nine-thing reflux indication file and eight-thing reflux discovering score. All patients were exposed to extraction of the laryngeal polyp by microlaryngoscopic medical procedure. The extracted tests were sent for human papilloma infection (HPV) identification by PCR. Laryngopharyngeal reflux (LPR) was introduced in 34 patients $(68 \%)$. Reflux side effect list went from 6 to 25 (mean $13.06 \pm 4.95$ ). Reflux discovering score went from 3 to 18 (mean $10.08 \pm$ 4.32). Seventeen patients (34\%) had positive HPV-6. Fifteen patients had positive HPV-6 out of 34 patients determined to have LPR $(44.11 \%)$, contrasted with just two patients had positive HPV-6 among 16 patients without LPR $(12.5 \%)(\mathrm{P}=$ 0.027). There were critical relations between presence of HPV-6 and both reflux side effect record and reflux discovering score; both were essentially higher among patients with positive HPV-6 $(\mathrm{P}=0.028)$ and $(\mathrm{P}<0.001)$ individually. Both laryngopharyngeal reflux and human papilloma infection assume significant related functions in the improvement of vocal crease polyps in grown-ups.
\end{abstract}

Keywords: Vocal fold polyp, Human papilloma virus, Laryngopharyngeal reflux.

\section{Introduction}

Grown-up vocal overlap polyps are by and large onesided generous sores influencing larynx, normally causing roughness of voice, rasp as well as voice weakness [1]. Be that as it may, uncommon cases have been accounted for with enormous or goliath polyps causing aviation route obstacle [2].

The mechanical harm is the fundamental driver for polyp arrangement either vocal over-and abuse or solid hacking. Smoking, gastroesophageal reflux, ongoing/intermittent upper respiratory contaminations, and hypersensitivity are considered as co-factors [3].

There are a few potential reasons for vocal crease polyps which can prompt expanded vocal overlay vein penetrability, neighborhood edema, hypoxia, degeneration, and fibrosis [4]. Laryngopharyngeal reflux (LPR) is a fiery state of the upper aerodigestive lot identified with impact of gastric or duodenal substance reflux, which prompts morphological changes in the upper aerodigestive parcel [5]. The laryngopharynx is more powerless than the throat to epithelial harm brought about by reflux, since the laryngopharynx has a dainty epithelium contrasted with the throat [6]. The higher predominance of laryngopharyngeal reflux scenes in patients with kindhearted genuine vocal overlay injuries supporting the idea of a direct harming impact of acidic gastric juice on the genuine vocal ropes [7].

Human papilloma infections are species-explicit infections, which show exacting tropism for the delineated squamous epithelium. More than 170 sorts have been recognized far to the point that can taint the skin or the mucosal surface of the aerodigestive lot, those infections can be delegated okay and high-hazard types
[8]. Laryngeal papilloma can be created and brought about by the human papilloma infection (HPV), most regularly of okay subtypes 6 and 11, which penetrates and multiplies inside epithelial tissue. This condition can show in one or the other adolescence or adulthood [9]. The genotype HPV-11 seems, by all accounts, to be related with more extreme structures, with an expanded danger of aviation route hindrance [10]. In any case, just $20 \%$ of patients with laryngeal papilloma have quantifiable degrees of human papilloma viral DNA [11]. Likewise, human papilloma infection can be inactive in vocal folds without laryngeal papillomas and viral DNA can be recognized by polymerase chain response (PCR) in the epithelium of the vocal ropes in patients experiencing ongoing laryngitis, knobs, or polyps mirroring the conceivable pervasiveness of idle HPV contaminations in the vocal line mucosa [12].

We pointed in this investigation to discover the significant functions of laryngopharyngeal reflux and human papilloma infection in the advancement of vocal overlap polyps in grown-up patients and to examine the conceivable relationship among LPR and HPV in grownup vocal overlay polyps.

\section{Materials and methods}

\subsection{Design and participants}

This investigation was done as a cross-sectional observational examination at Benha University Hospital, Benha workforce of medication, Benha, Egypt; during the period from May 2018 to August 2020. Fifty grownup patients were incorporated, experiencing roughness of voice because of quality of vocal crease polyp and introduced to the out-persistent facility of the clinic. 
We rejected from the investigation patients more youthful than 18 years, patients with history of laryngeal medical procedure, patients with history of laryngeal malignancy, and additionally patients with history of injury to larynx.

Educated composed assent was acquired from all members in the investigation. The examination was acted as per the Helsinki affirmation and its changes, the investigation convention was endorsed by the Research Ethics Committee at Faculty of Medicine, Benha University (REC-FOMBU), Egypt.

\subsection{Preoperative assessment}

Detailed history was obtained including the demographic data and history of the condition; onset, course, duration, frequency of exacerbations, and development of any complications. Full otorhinolaryngology examination of ear, nose, and throat was completed. Then examination of the larynx by video laryngostroboscopy was performed to detect the presence of laryngeal polyps and to document the physical findings of laryngopharyngeal reflux (LPR).

Subjectively, all patients were evaluated for the presence of symptoms of LPR such as intermittent dysphonia, vocal fatigue, voice breaks, chronic throat clearing, excessive throat mucus, chronic cough, and/or chronic airway obstruction. The nine-item reflux symptom index (RSI) was applied, it is a developed and validated questionnaire to quantify patient's symptoms of LPR and evaluate treatment efficacy. The scores of this questionnaire range from 0 (normal) to 45 (most severe). This validated questionnaire has displayed excellent reproducibility and criterion-based validity [13].

Objectively, the laryngeal examination findings were recorded, the possible signs of LPR can range from vocal fold hyperemia or edema, subglottic edema or diffuse laryngeal edema, ventricular obliteration, posterior commissure hypertrophy and/or granuloma. The eightitem reflux finding score (RFS) was applied, it is a validated tool to document the physical findings severity of LPR. The scores of this tool range from 0 (normal) to 26 (most severe) [14].

A score of reflux symptom index (RSI) greater than 13 , or reflux finding score (RFS) above 7 points, were considered positive and clinically diagnostic and indicative of LPR $[15,16]$.

\subsection{Operative procedure}

All patients were subjected to excision of the vocal fold polyp by direct microlaryngoscopy under general anesthesia. The excision samples were sent to microbiology department to search for human papilloma virus by polymerase chain reaction (PCR).

\subsection{Detection of HPV by PCR}

Human papilloma virus genome detection was done by a multiplex PCR-based HPV typing assay using typespecific primers and agarose gel electrophoresis as described by Romero-Pastrana in 2012, [17].

\subsubsection{DNA extraction from paraffin sections}

The formalin-fixed, paraffin-embedded (FFPE) tissue specimens from fifty patients were analyzed. After cutting deep into the block, eight $10 \mu \mathrm{m}$-sections of formalin-fixed paraffin embedded tissue were transferred to Eppendorf vials. Total DNA was extracted using QIAamp DNA FFPE Tissue (Qiagen, Hilden, Germany).

Deparaffinization of the sections were done by vortexing and incubation with xylene. Then xylene was decanted and its residue was removed by two pure ethanol washes. The air-dried pellet was then incubated for 10 hours with $25 \mu \mathrm{L}$ of proteinase $\mathrm{K}$ and $250 \mu \mathrm{L}$ of ATL lysis buffer in a heat block at $56^{\circ} \mathrm{C}$. The lysed emulsion was further purified with the spin-column kit. Finally, DNA was eluted in $50 \mu \mathrm{l}$ of AE buffer $(0.5 \mathrm{mM}$ EDTA) and then stored at $-20^{\circ} \mathrm{C}$ for further use.

\subsubsection{DNA amplification}

Amplification was performed using forward primer (5'-ACG TGG CCT TGT GCG GTA CAG TC -3') and reverse primer (5'-AGA GAC GAG TCA GGC AAT GC $\left.-3^{\prime}\right)$. The reaction was performed in a total volume of 25 $\mu \mathrm{L}$ composed of $1 \mu \mathrm{L}$ of each primer, $5 \mu \mathrm{L}$ of extracted DNA, $12.5 \mu \mathrm{L}$ of Easy Taq ${ }^{\circledR}$ Universal PCR SuperMix (TransGen Biotech, Haidian District, Beijing, China), and $5.5 \mu \mathrm{L}$ of nuclease free water.

Amplification was done according to the protocol of: initial denaturation step at $95^{\circ} \mathrm{C}$ for $15 \mathrm{~min}, 10$ cycles of $30 \mathrm{~s}$ at $94^{\circ} \mathrm{C}, 90 \mathrm{~s}$ at $65^{\circ} \mathrm{C}$, and $90 \mathrm{~s}$ at $72^{\circ} \mathrm{C}$, followed by 30 cycles of $30 \mathrm{~s}$ at $94^{\circ} \mathrm{C}, 90 \mathrm{~s}$ at $63^{\circ} \mathrm{C}$, and $90 \mathrm{~s}$ at $72^{\circ} \mathrm{C}$, with a final extension at $72^{\circ} \mathrm{C}$ for $10 \mathrm{~min}$.

\subsubsection{Detection of PCR amplification products}

The amplified samples were then run in on $2 \%$ agarose gel, in the presence of a DNA marker, using gel electrophoresis and visualized on a UV transilluminator to detect presence of amplified product and to type the HPVgenome.

\subsection{Statistical analysis}

Obtained data were statistically analyzed using SPSS version 16 software (SPSS Inc, Chicago, IL, USA). "Chi-square test" was used to analyze categorical data. While "two sample $t$ test" was used to analyze quantitative data. P-value $\leq 0.05$ was considered the accepted level of significance in this work.

\section{Results}

Fifty patients were included in this observational study, their ages ranged from 30 to 52 years with (mean age $38.94 \pm 5.18$ years). Male to female ratio represented $44 \%$ to $56 \%$ of the studied patients.

Laryngopharyngeal reflux was diagnosed in 34 (68\%) patients. Reflux symptom index (RSI) ranged from 6 to 25 with mean of $(13.06 \pm 4.95)$. Reflux finding score (RFS) ranged from 3 to 18 with mean of (10.08 \pm 4.32). Regarding HPV testing, 17 samples (34\%) of the studied patients had positive HPV-6 while no one $(0 \%)$ had positive HPV-11 Table (1). 
Table (1) Findings in total studied patients.

\begin{tabular}{|c|c|c|}
\hline Variant & & $\begin{array}{c}\text { Total patients } \\
\text { n (50) }\end{array}$ \\
\hline \multicolumn{3}{|l|}{ Age (years) } \\
\hline $\begin{array}{l}\text { Mean } \pm \text { SD } \\
\text { (Range) }\end{array}$ & & $\begin{array}{c}38.940 \pm 5.180 \\
\quad(30-52)\end{array}$ \\
\hline Sex & n $(\%)$ & \\
\hline Male & & $22(44 \%)$ \\
\hline Female & & $28(56 \%)$ \\
\hline LPR & n $(\%)$ & \\
\hline Absent & & $16(32 \%)$ \\
\hline Present & & $34(68 \%)$ \\
\hline \multicolumn{3}{|l|}{ RSI } \\
\hline $\begin{array}{l}\text { Mean } \pm \text { SD } \\
\text { (Range) }\end{array}$ & & $\begin{array}{c}13.060 \pm 4.950 \\
(6-25)\end{array}$ \\
\hline \multicolumn{3}{|l|}{ RFS } \\
\hline $\begin{array}{l}\text { Mean } \pm \text { SD } \\
\text { (Range) }\end{array}$ & & $\begin{array}{c}10.080 \pm 4.322 \\
(3-18)\end{array}$ \\
\hline HPV-6 & n $(\%)$ & \\
\hline Negative & & $33(66 \%)$ \\
\hline Positive & & $17(34 \%)$ \\
\hline HPV-11 & n $(\%)$ & \\
\hline Negative & & $50(100 \%)$ \\
\hline Positive & & $0(0 \%)$ \\
\hline
\end{tabular}

HPV-6: human papilloma virus subtype 6; HPV-11: human papilloma virus subtype 11; LPR: laryngopharyngeal reflux; RFS: reflux finding score; RSI: reflux symptom index

As shown in Table (2), there was non-significant relation between presence of laryngopharyngeal reflux and either age or gender. But there was a statistically significant association between presence of LPR and HPV-6 genome detection. Positive HPV-6 was present in 15 out of $34(44.11 \%)$ patients with present LPR, compared to only two patients out of 16 (12.5\%) of those without reflux $(\mathrm{P}=0.027)$.

There was non-significant relation between HPV-6 genome detection and either age or gender. But, the total 17 patients with positive samples for HPV-6 showed a statistically significant association between the presence of HPV-6 and both reflux severity index (RSI) and reflux finding score (RFS). Both were significantly higher among patients with positive HPV-6, $(\mathrm{P}=0.028)$ and $(\mathrm{P}$ $<0.001)$ respectively Table (3).

Table (2) Comparison between laryngopharyngeal reflux present and absent cases.

\begin{tabular}{|c|c|c|c|c|c|}
\hline \multirow{2}{*}{\multicolumn{2}{|c|}{ Variant }} & \multirow{2}{*}{\multicolumn{2}{|c|}{ LPR }} & \multirow{2}{*}{\multicolumn{2}{|c|}{ Test }} \\
\hline & & & & & \\
\hline \multicolumn{6}{|c|}{ Age (years) } \\
\hline & $\begin{array}{l}\text { Mean } \pm \text { SD } \\
\text { (Range) }\end{array}$ & $\begin{array}{c}39.323 \pm 5.649 \\
(30-52)\end{array}$ & $\begin{array}{c}38.125 \pm 4.047 \\
(33-47)\end{array}$ & 0.759 & 0.451 \\
\hline \multirow[t]{3}{*}{ Sex } & $\mathrm{n}(\%)$ & & & & \\
\hline & Male & $16(47.05)$ & $6(37.50)$ & 0.403 & 0.525 \\
\hline & $\begin{array}{l}\text { Female } \\
\mathrm{n}(\%)\end{array}$ & $18(52.94)$ & $10(62.50)$ & & \\
\hline \multirow{2}{*}{ HPV-6 } & Negative & $19(55.88)$ & $14(87.50)$ & 4.846 & 0.027 \\
\hline & Positive & $15(44.11)$ & $2(12.50)$ & & \\
\hline
\end{tabular}

HPV-6: human papilloma virus subtype 6; LPR: laryngopharyngeal reflux.

Table (3) Comparison between HPV-6 negative and positive cases. 


\begin{tabular}{|c|c|c|c|c|c|}
\hline \multicolumn{2}{|c|}{ Variant } & \multicolumn{2}{|c|}{ HPV-6 } & \multicolumn{2}{|c|}{ Test } \\
\hline \multirow{2}{*}{\multicolumn{6}{|c|}{ Age (years) }} \\
\hline & & & & & \\
\hline & $\begin{array}{l}\text { Mean } \pm \text { SD } \\
\text { (Range) }\end{array}$ & $\begin{array}{c}39.151 \pm 4.981 \\
(30-52)\end{array}$ & $\begin{array}{c}38.529 \pm 5.680 \\
(32-49)\end{array}$ & 0.398 & 0.691 \\
\hline \multirow[t]{3}{*}{ Sex } & $\mathrm{n}(\%)$ & & & & \\
\hline & Male & $15(45.45)$ & $7(41.17)$ & 0.083 & 0.772 \\
\hline & Female & $18(54.54)$ & $10(58.82)$ & & \\
\hline \multirow[t]{3}{*}{ LPR } & n (\%) & & & & \\
\hline & Yes & $19(57.57)$ & $15(88.23)$ & 4.846 & 0.027 \\
\hline & No & $14(42.42)$ & $2(11.76)$ & & \\
\hline \multicolumn{6}{|c|}{$1+(42 .+2)$} \\
\hline & $\begin{array}{l}\text { Mean } \pm \text { SD } \\
\text { (Range) }\end{array}$ & $\begin{array}{c}11.969 \pm 4.882 \\
(6-24)\end{array}$ & $\begin{array}{c}15.176 \pm 4.489 \\
(8-25)\end{array}$ & 2.258 & 0.028 \\
\hline RFS & $\begin{array}{l}\text { Mean } \pm \text { SD } \\
\text { (Range) }\end{array}$ & $\begin{array}{c}8.636 \pm 3.879 \\
(3-16)\end{array}$ & $\begin{array}{c}12.882 \pm 3.805 \\
(5-18)\end{array}$ & 3.689 & 0.0006 \\
\hline
\end{tabular}

HPV-6: human papilloma virus subtype 6; LPR: laryngopharyngeal reflux; RFS: reflux finding score; RSI: reflux symptom index.

\section{Discussion}

The inert and subclinical diseases of human papillomavirus (HPV) have acquired interest, yet there is little data about the commonness of idle HPV contaminations in the larynx [12]. Plainly generally safe HPV contamination is the dominating causative specialist of adolescent laryngeal papillomatosis, yet in grown-up beginning laryngeal papilloma, the condition is normally multifactorial [3,18]. Then again, the vocal overlay mucosa in grown-up patients without papillomas (without morphological proof of a HPV-related injury), yet enduring ongoing laryngitis, vocal line knobs, or polyps could have discernible human papilloma viral genome by PCR [12].

Persistent laryngeal disturbance, independent of the particular aggravation, may prompt morphologic changes in the larynx including polyp arrangement. Laryngopharyngeal reflux (LPR) disturbs the laryngopharyngeal mucosa causing side effects and indications of persistent reflux laryngitis. The commonness of LPR has been continually expanding these days influencing high level of everyone [7].

The investigation of Formánek et al., expressed that the LPR may be a danger factor for grown-up laryngeal papilloma or polyps by initiating or reactivating a dormant HPV contamination [19]. They prescribed extra examinations with bigger accomplices to affirm their discoveries and to clear up the systems in question. The point of the current work was to examine the significant parts of laryngopharyngeal reflux and human papilloma infection in the advancement of grown-up vocal overlap polyps and to contemplate the conceivable relationship among LPR and HPV in this substance through appraisal of the predominance of human papillomavirus (HPV) in patients gave grown-up vocal overlay polyp and experiencing laryngopharyngeal reflux (LPR).
In the current investigation, we included 50 patients with grown-up central overlap polyps, the time of patients went from 30 to 52 years with a mean period of $38.94 \pm 5.18$ years, 28 of the patients were females $(56 \%)$ and 22 were guys $(44 \%)$, this matches with Martins et al., [20] who contemplated the clinical and morphological attributes of 76 patients with vocal crease polyps and found that the age ran somewhere in the range of 21 and 60 years with male to female proportion spoke to $43 \%$ to $57 \%$. Our outcomes additionally coordinates with Yun et al., [21] who contemplated 175 patients with vocal overlap polyps, $58.8 \%$ were female and $41.2 \%$ were male, their age ran between 24 to 78 years. This implies that grown-up vocal crease polyps do happen in a wide age range and not sexual orientation related.

In the current investigation, the commonness of laryngopharyngeal reflux (LPR) among the patients with grown-up vocal overlap polyp was $(68 \%)$ and was not identified with age or sexual orientation. This goes in accordance with the investigations of Beltsis et al. [7] and Chung et al. [22], both utilized $\mathrm{pH}$ checking for determination of the reflux and the two investigations found that LPR introduced in $(75 \%)$ of patients with genuine grown-up vocal overlay polyps. Likewise, Wang et al., [23] who examined 32 patients submitted to laryngeal medical procedure for vocal polyps, uncovered a fundamentally higher presence of pepsin $(75 \%)$ in patients with vocal polyps when contrasted and the benchmark group $(31.25 \%)$.

In our investigation we utilized the reflux side effect list (RSI) and the reflux discovering score (RFS) as clinically non-intrusive straightforward indicative instruments of LPR. Albeit 24-h twofold test mobile $\mathrm{pH}$ observing is viewed as the highest quality level for LPR conclusion, however number of studies have had the 
option to approve the RSI and RFS evaluations as demonstrative trial of LPR [14,16,24].

With respect to genome discovery, we discovered 17 examples speaking to $(34 \%)$ of the considered patients had positive HPV-6 while nobody $(0 \%)$ had positive HPV-11. Our outcomes were higher than Rihkanen et al. [12] who distinguished the infection in the epithelium of (19\%) of patients worked for persistent laryngitis, knobs, and polypi without laryngeal papillomas. The predominance of HPV in our examination was similar to past investigations on grown-up papillomas as Makiyama et al., [25] who found that $(46.1 \%)$ of patients with grown-up laryngeal papilloma were positive for HPV-6 and (7.6\%) were positive for HPV-11, yet their examination included moderately more modest number of members (13 patients). Hirai et al. [26] found a higher predominance of generally safe HPV $(66.7 \%)$ in grownup patients with laryngeal papillomas. The way that we found the paces of event of the infection in instances of polyps approximates somewhat the paces of event in instances of grown-up papillomas, this demonstrates the presence of inactive infection in the laryngeal mucosa.

From the consequences of our investigation, it appears to be that there is a solid connection and relationship between recognition of HPV-6 genome and LPR in cases with grown-up vocal crease polyps. Laryngopharyngeal reflux was available in 15 out of 17 (88.23\%) patients with positive HPV-6. Supporting this relationship in the current investigation, there were factually critical higher reflux seriousness record (RSI) and reflux discovering score (RFS) among patients with positive HPV-6. Formánek et al. [19] noticed the relationship between the laryngopharyngeal reflux (pepsin in tissue) and human papilloma infection identification in grown-up laryngeal papilloma. They examined 20 intermittent instances of vocal papilloma, HPV was found in the entirety of the biopsies, and pathologic LPR was analyzed in $(40.0 \%)$, accordingly may be conceivable danger factors for this sickness.

Past examinations proposed a connection between the presence of extraesophageal indigestion infection and repetitive respiratory papillomatosis in youngsters $[27,28]$. They speculated that the irritation prompted by ongoing corrosive presentation may bring about the declaration of HPV in helpless tissues. Our discoveries in grown-up vocal overlap polyps in regards to the critical discovery of HPV-6 genome in $(44.11 \%)$ of patients with LPR, uphold this speculation in grown-ups. Laryngopharyngeal reflux might be one of the elements which lead to human papilloma infection enactment. The location of HPV genome in the extraction biopsies of grown-up vocal overlay polyps might be helpful as an etiological factor especially whenever related with manifestations and indications of laryngeopharyngeal reflux.

\section{Conclusion}

Both laryngopharyngeal reflux and human papilloma infection assume significant parts in the improvement of vocal overlay polyps in grown-ups and there is a potential relationship among LPR and HPV in this element as the predominance of human papillomavirus (HPV) in patients gave grown-up vocal overlap polyp and experiencing laryngopharyngeal reflux (LPR) was essentially higher than that in patients not enduring LPR. There were factually critical higher reflux seriousness file (RSI) and reflux discovering score (RFS) among patients with positive HPV-6.

In light of these discoveries and results, future investigations are suggested toward conceivable adjuvant antiviral treatment after extractions of grown-up vocal overlay polyps especially whenever related with manifestations and indications of laryngopharyngeal reflux.

\section{Funding sources}

This research did not receive any specific grant from funding agencies in the public, commercial, or not-forprofit sectors.

\section{Conflict of interest}

The authors declare no conflict of interest.

\section{Ethics and Consent}

Informed written consent was obtained from all participants in the study. The study was performed in accordance with the Helsinki declaration and its amendments, The study protocol was approved by the Research Ethics Committee at Faculty of Medicine, Benha University (REC-FOMBU), Egypt.

\section{Availability of data and material}

The data that support the findings of this study are available from the corresponding author upon reasonable request.

\section{References}

[1] D.Vasconcelos, A.O.C.Gomes, C.M.T.Araújo, Vocal Fold Polyps: Literature Review. Int Arch Otorhinolaryngol. Jan, Vol.23(1),PP.116-124, 2019.

[2] T.Kusunoki, R.Fujiwara, K.Murata, K.Ikeda. A giant vocal fold polyp causing dyspnea. Ear Nose Throat J. Vol.88(12),PP.1248-9,2009.

[3] R.B.Nunes, M.Behlau, M.B.Nunes, J.G. Paulino,Clinical diagnosis and histological analysis of vocal nodules and polyps. Braz J Otorhinolaryngol, Vol.79(4),PP.434-40,2013.

[4] J.Bohlender, Diagnostic and therapeutic pitfalls in benign vocal fold diseases. GMS Curr Top Otorhinolaryngol Head Neck Surg, Vol.13,PP.12:Doc01, 2013.

[5] J.R.Lechien, S.Saussez, A.Nacci, M.R.Barillari, Rodriguez A, Le Bon SD, et al. Association between laryngopharyngeal reflux and benign vocal folds lesions: A systematic review. Laryngoscope, Vol.129(9),PP.E329-E341,2019.

[6] S.E.Axford, N. Sharp, P.E.Ross, J.P.Pearson, Cell biology of laryngeal epithelial defenses in health and disease: preliminary studies. Ann 
OtolRhinolLaryngol, Vol.110(12),PP.1099-108, 2001.

[7] A.Beltsis, P.Katsinelos, J.Kountouras, N.Kamarianis, Double probe $\mathrm{pH}$-monitoring findings in patients with benign lesions of the true vocal folds: comparison with typical GERD and the effect of smoking. Eur Arch Otorhinolaryngol, Vol.268(8),PP.1169-1174, 2011.

[8] M.G.Donà, B.Pichi, F.Rollo, T.Gheit, Mucosal and cutaneous human papillomaviruses in head and neck squamous cell papillomas. Head Neck, Vol.39(2),PP.254-259,2017.

[9] H.R.Fortes, F.M.von Ranke, D.L.Escuissato, C.A.Araujo Neto, Recurrent respiratory papillomatosis: A state-of-the-art review. Respir Med, Vol.126,PP.116-121,2017.

[10] M.Ilboudo, T.M. Zohoncon, I.M.A.Traore, E.M.A. Implication of low risk human papilloma viruses, HPV6 and HPV11 in laryngeal papillomatosis in Burkina Faso. Am J Otolaryngol, Vol.40(3),PP.368-371,2019.

[11] J.E.McClay, eMedicine Medscape, Drugs \& Diseases, Otolaryngology and Facial Plastic Surgery, Recurrent Respiratory Papillomatosis Surgery, 2020.

[12] H.Rihkanen, J. Peltomaa, S.Syrjänen, Prevalence of human papillomavirus (HPV) DNA in vocal cords without laryngeal papillomas. Acta Otolaryngol. May, Vol.114(3),PP.348-51, 1994.

[13] P.C.Belafsky, G.N.Postma, J.A.Koufman. Validity and reliability of the reflux symptom index (RSI). J Voice. Jun, Vol.16(2),PP.274-7,2002.

[14] P.C.Belafsky, G.N.Postma, J.A.Koufman, Laryngopharyngeal reflux symptoms improve before changes in physical findings. Laryngoscope. Jun, Vol.111(6),PP.979-81,2001.

[15] T.A.Mesallam, J.C.Stemple, T.M.Sobeih, R.G. Elluru, Reflux symptom index versus reflux finding score. Ann OtolRhinolLaryngolJun, Vol.116(6),PP.436-40,2007.

[16] H.S.Nunes, J.A.Pinto, A.R.Zavanela, A.F.Cavallini, Comparison between the Reflux Finding Score and the Reflux Symptom Index in the Practice of Otorhinolaryngology. Int Arch Otorhinolaryngol. Jul, Vol.20(3),PP.218-21,2016.

[17] F.Romero-Pastrana, Detection and typing of human papilloma virus by multiplex PCR with typespecific primers. ISRN Microbiol. Mar, Vol. $1 ;$;PP.186915,2012.
[18] J.Li, T.Y.Zhang, L.T .Tan, S.Y.Wang, Expression of human papillomavirus and prognosis of juvenile laryngeal papilloma. Int J Clin Exp Med. Sep 15, Vol.8(9),PP.15521-7, 2015.

[19] M.Formánek, D.Jančatová, P.Komínek, P.Matoušek, Laryngopharyngeal reflux and herpes simplex virus type 2 are possible risk factors for adult-onset recurrent respiratory papillomatosis (prospective case-control study). Clin Otolaryngol. Jun, Vol.42(3),PP.597-601, 2017.

[20] R.H.Martins, J.Defaveri, M.A. Domingues, de Albuquerque e Silva R. Vocal polyps: clinical, morphological, and immunohistochemical aspects. J Voice. Jan, Vol.25(1),PP.98-106,2011.

[21] Y.S .Yun, M.B.Kim, Y.I.Son. The effect of vocal hygiene education for patients with vocal polyp. Otolaryngol Head Neck Surg. Oct, Vol.137(4),PP.569-75,2007.

[22] J.H.Chung, K.Tae, Y.S.Lee, J.H.Jeong, The significance of laryngopharyngeal reflux in benign vocal mucosal lesions. Otolaryngol Head Neck Surg. Sep;, Vol.141(3),PP.369-73,2009.

[23] L.Wang, J.J.Tan, T.Wu, R.Zhang, Association between Laryngeal Pepsin Levels and the Presence of Vocal Fold Polyps. Otolaryngol Head Neck Surg. Jan, Vol.156(1),PP.144-151,2017.

[24] A.L.Merati, H.J.Lim, S.O.Ulualp, R.J.Toohill. Meta-analysis of upper probe measurements in normal subjects and patients with laryngopharyngeal reflux. Ann Otol Rhinol Laryngol. Mar, Vol.114(3),PP.177-82,2005.

[25] K.Makiyama, R.Hirai, H.Matsuzaki, M.Ikeda. Assessment of human papilloma virus infection in adult laryngeal papilloma using a screening test. J Voice. Mar, Vol.27(2),PP.230-5,2013.

[26] R.Hirai, K.Makiyama, Y.Higuti, A.Ikeda, Pharyngeal squamous cell papilloma in adult Japanese: comparison with laryngeal papilloma in clinical manifestations and HPV infection. Eur Arch Otorhinolaryngol. Oc, Vol.269(10),PP.22716,2012 .

[27] G.Borkowski, P.Sommer, T.Stark, H.Sudhoff, Recurrent respiratory papillomatosis associated with gastroesophageal reflux disease in children. Eur Arch Otorhinolaryngol, Vol.256(7),PP.3702,1999.

[28] M.McKenna, L.Brodsky, Extraesophageal acid reflux and recurrent respiratory papilloma in children. Int J Pediatr Otorhinolaryngol. May, Vol.69(5),PP.597-605,2005. 